\title{
Legislative Bill Drafting
}

\section{Correct Drafting Important}

$\mathrm{T}$

HE drafting of legislative bills is an important phase of legislation. During the last six sessions of the legislature 13,987 bills were introduced. Most of the members of the legislature have no legal training and their attention is directed primarily to the substance rather than the form of the proposed laws. The large number of bills makes careful consideration of the substance of the proposed acts difficult and the checking of the drafting practically impossible, especially since some errors in drafting do not appear on the face of the bills.

If, then, statutes are to be enacted which will not be found to be in violation of the constitution, which fulfill the purpose for which they were passed and which do not modify laws which they were not intended to affect, the bills presented to the legislature must be properly drawn.

The drafting of legislative bills is a tedious and technical problem, which, to be properly done, requires both a broad knowledge of law and great care in drafting. One cannot intelligently undertake to draft an important bill on any subject until he is familiar with the principles of the common law involved and with all the statutory provisions on the subject.

Many bills are presented at each session of the legislature which are poorly drawn; some of these show the draftsman to have had a mastery of the substance of the law but to have been unacquainted with the practice or the requirements of good bill drafting. This article is directed to the problem of the drafting of bills.

It is the purpose of this article to summarize the provisions of law relating to the purpose, form and drafting of bills and to outline the practice of bill drafting as it has developed in this state.

The constitution, Article IV, section 15, requires that "No law shall be passed except by bill'".

\section{The Field of Legislation}

The problem of bill drafting is complicated by certain constitutional provisions which limit the purposes which may be accomplished by, and the methods which may be used in legislation.

These provisions prohibit the passage of local and special acts 
in certain cases; the giving of state aid to private or sectarian institutions in most cases; the lending of public credit except in case of veterans' welfare work; and the making of gifts or the granting of extra compensation.

\section{General and Spectal Acts}

The prohibition against local and special acts is found in Article IV, section 25 of the constitution, and is as follows:

"The Legislature shall not pass local or special laws in any of the following enumerated cases, that is to say:

First-Regulating the jurisdiction and duties of justices of the peace, police judges, and of constables.

Second-For the punishment of crimes and misdemeanors.

Third-Regulating the practice of courts of justice.

Fourth-Providing for changing the venue in civil or criminal actions.

Fifth-Granting divorces.

Sixth-Changing the names of persons or places.

Seventh-Authorizing the laying out, opening, altering, maintaining or vacating roads, highways, streets, alleys, town plots, parks, cemeteries, graveyards, or public grounds not owned by the state.

Eighth-Summoning and impaneling grand and petit juries, and providing for their compensation.

Ninth-Regulating county and township business, or the election of county and township officers.

Tenth-For the assessment or collection of taxes.

Eleventh-Providing for conducting elections or designating the places of voting, except on the organization of new counties.

Twelfth-Affecting estates of deceased persons, minors, or other persons under legal disabilities.

Thirteenth-Extending the time for the collection of taxes.

Fourteenth-Giving effect to invalid deeds, wills, or other instruments.

Fifteenth-Refunding money paid into the state treasury.

Sixteenth-Releasing or extinguishing, in whole or in part, the indebtedness, liability, or obligation, of any corporation or person to this state, or to any municipal corporation therein.

Seventeenth-Declaring any person of age, or authorizing any minor to sell, lease or incumber his or her property.

Eighteenth-Iegalizing, except as against the state, the unauthorized or invalid act of any officer.

Nineteenth-Granting to any corporation, association, or individual any special or exclusive right, privilege or immunity.

Twentieth-Exempting property from taxation.

Twenty-first-Changing county seats.

Twenty-second-Restoring to citizenship persons convicted of infamous crimes. 
Twenty-third-Regulating the rate of interest on money.

Twenty-fourth-Authorizing the creation, extension or impairing of liens.

Twenty-fifth-Chartering or licensing ferries, bridges or roads.

Twenty-sixth-Remitting fines, penalties, or forfeitures.

Twenty-seventh-Providing for the management of common schools.

Twenty-eighth-Creating offices, or prescribing the powers and duties of officers in counties, cities, cities and counties, townships, election or school districts.

Twenty-ninth-Affecting the fees or salary of any officer.

Thirtieth-Changing the law of descent or succession.

Thirty-first-Authorizing the adoption or legitimation of children.

Thirty-second-For limitation of civil or criminal actions.

Thirty-third-In all other cases where a general law can be made applicable."

It will be noticed that there are thirty-two cases enumerated in which local or special acts may never be passed, and that such acts may be passed in other cases only when a general law can not be made applicable. ${ }^{1}$

A general act has been defined as one which applies to the whole community, in contrast to a special or local act which relates only to particular persons or things. ${ }^{2}$

There is no definite dividing line between general and special or local acts. But while there is unfortunately no rule by which every act can be determined to be either general or special, there is in general a clear distinction between the two classes of acts, and there is no reason why the constitutionality of any act which is properly drawn should be subject to question.

\section{General Acts}

The following are examples of acts which have been held to be general :

An act relating to the election of boards of freeholders to adopt and amend charters. ${ }^{3}$

An act applying to elections in towns and cities."

1 Argyle Dredging Co. v. Chambers (1920) 40 Cal. App. 332, 181 Pac. 84.

2 Ex parte Burke (1881) 59 Cal. 6, 43 Am. Rep. 231.

3 Fragley v. Phelan (1899) 126 Cal. 383, 58 Pac. 923. Pac. 175.

4 Vernon School District v. Board of Education (1899) 125 Cal. 593, 58 
An act providing for an action by a reclamation district to determine the validity of an assessment. ${ }^{5}$

An act providing for a special method for levying a tax for high schools, different from that provided for other school districts. ${ }^{8}$

An act making it a felony to sell intoxicating liquors to Indians. ${ }^{7}$

An act providing for vaccination of all children attending public schools. ${ }^{8}$

An act relating to the compensation of the auditor and his clerk in counties of the twentieth class. ${ }^{9}$

An act applying to all foreign corporations and providing for filing designation of agents, service of process and proof of corporate existence. ${ }^{10}$

An act forbidding employment of children under the age of sixteen years in dangerous or immoral places. ${ }^{11}$

An act providing for the establishment of title to land where the records were destroyed by fire and making provisions regulating practice not found in other judicial proceedings. ${ }^{12}$

A curative act as to all tax deeds defective in not stating the time allowed for redemption. ${ }^{13}$

An act regulating employment in underground mines and in smelting and reduction works. ${ }^{14}$

An act forbidding the employment of women for more than eight hours a day in certain places. ${ }^{25}$

\section{Special Acts}

A few examples will also clearly illustrate the types of acts which have been held to be in violation of the constitutional provisions prohibiting special and local acts.

The following cases have been held to be local or special:

An act providing for boards of election commissioners in cities and counties having one hundred and fifty thousand or more inhabitants, that being an arbitrary classification, without reference to existing classification of cities. ${ }^{18}$

sower Kings River Reclamation District No. 531 v. McCullah (1899) 124 Cal. 175, 56 Pac. 887.

- People v. Lodi High School District (1899) 124 Cal. 694, 57 Pac. 660.

7 People v. Bray (1894) 105 Cal. 344, 38 Pac. 731.

8 Abeel v. Clark (1890) 84 Cal. 226, 24 Pac. 383.

9 Farnum v. Warner (1894) 104 Cal. 677, 38 Pac. 421.

10 Anglo-Californian Bank v. Field (1905) 146 Cal. 644, 80 Pac. 1080.

11 In re Weber (1906) 149 Cal. 392, 86 Pac. 809.

12 Title Restoration Co. v. Kerrigan (1906) 150 Cal. 289, 88 Pac. 356,

119 Am. St. Rep. 199, 8 L. R. A. (N. S.) 682.

13 Baird v. Monroe (1907) $150 \mathrm{Cal} .560,89 \mathrm{Pac} .352$.

14 In re Martin (1909) 157 Cal. 51, 106 Pac. 235, 26 I. R. A. (N. S.) 242.

15 In re Miller (1912) 162 Cal. 687, 124 Pac. 427.

${ }^{16}$ Denman v. Broderick (1896) 111 Cal. 96, 43 Pac. 516. 
Provision in a county government act for salaries in addition to fees for constables in certain townships in a county of a particular class. ${ }^{17}$

An act giving laborers employed by corporations by the week or month a lien for wages. ${ }^{18}$ vote. ${ }^{19}$

A law arbitrarily depriving certain persons of the right to

An act directed at and applicable to one particular named municipal corporation. ${ }^{20}$

A law regulating the rate of interest on chattel mortgages on certain classes of property only.21

The provision in the mechanics' lien law allowing the plaintiff, but not the defendant, attorney's fees. ${ }^{22}$

\section{Certain Special Acts Authorized}

Special or local acts are specifically authorized in certain cases. The legislature is authorized by Article IV, section $25 \mathrm{~T} / 2$ to divide the State into Fish and Game Districts and to "enact such laws for the protection of fish and game therein as it may deem appropriate to the respective districts". An act is not special under this section when it applies uniformly to an entire fish and game district. ${ }^{23}$

The classification of counties is authorized by Article XI, section 5 of the constitution, for the purpose of fixing the salaries of the county officers, but it is clear that the classification may be used for no other purpose. It is said in Payne v. Murphy, ${ }^{24}$

"It seems to be conceded by all parties that the power of the legislature to classify counties by population is a power to be exercised for the limited purpose of enabling the compensation of the various officers to be fixed and adjusted. The Constitution, in Section 5 of Article XI, seems to make that proposition very clear, and our supreme court has so held in a number of cases, of which we cite: Pratt v. Browene, 135 Cal. 469; (67 Pac. 1082) ; Sanchez v. Fordyce, 141 Cal. 427, (75 Pac. 56.)" The counties have been classified in the order of the greater population, each county being in a separate class.

${ }_{17}$ Lougher v. Sote (1900) 129 Cal. 610, 62 Pac. 184.

${ }_{18}$ Slocum v. Bear Valley Irrigation Co. (1898) 122 Cal. 555, 55 Pac. 403, 68 Am. St. Rep. 68.

10 Spier v. Baker (1898) 120 Cal. 370, 52 Pac. 659, 41 L. R. A. 196.

20 People v. Common Council (1890) 85 Cal. 369, 24 Pac. 727.

21 Ex parte Sohncke (1905) 148 Cal. 262, 82 Pac. 956, 113 Am. St. Rep. 236, 2 I. R. A. (N. S.) 813 .

22 Builders' Supply Depot v. O'Conner (1907) 150 Cal. 265, 88 Pac. 982, 119 Am. St. Rep. 193, 17 L. R. A. (N. S.) 909.

23 Paladini v. Superior Court (1918) 178 Cal. 369, 173 Pac. 588; Matter of Application of Mascola (1914) 25 Cal. App. 92 ; 142 Pac. 903.

24 (1912) 18 Cal. App. 446, 447, 123 Pac. 350. 
Article XI, section 6, of the constitution authorizes the classification of cities and towns according to population. The cities have been classified in such a manner that each of the larger cities is in a separate class.

Special acts relating to state highways are authorized by Article IV, section 36 of the constitution.

\section{Spectal Acts Under the First Constitution}

Special acts were not forbidden by the first constitution. ${ }^{25}$ The provisions added to the second constitution were prospective only, and do not affect statutes passed prior to their adoption nor destroy the force of then existing special laws. ${ }^{26}$

\section{Classification}

In order to meet local or special conditions, which could not be met by an act applying uniformly to all of the people or to all parts of the state, the legislature has frequently resorted to classification.

The law governing classification has been very well summarized in the case of Martin v. Superior Court of Sacramento, ${ }^{27}$ as follows:

"A law is not special legislation merely because it does not apply to all persons. It is a settled principle of constitutional law that the legislature may classify for the purpose of meeting different conditions, naturally requiring different legislation, in order that legislation may be adapted to the needs of the people. If the law is to bear equally on all persons, the legislature must classify whenever there exists a reason which may rationally be held to justify a diversity of legislation. In other words, different persons, different localities and different governmental organizations and agencies may justly be found by the legislature to stand in different relations to the law; and if the same law were, in such a situation to be applied to all alike, it would not bear equally upon each of them. (Darcy v. Mayor etc. of the City of San Jose, 104 Cal. 642; In re Sumida, 177 Cal. 388.)

"The classification, however, must not be arbitrarily made for the mere purpose of classification, but must be based upon

${ }_{25}$ Nevada School Dist. v. Shoecraft (1891) 88 Cal. 372, 26 Pac. 211.

26 Vallejo Ferry Co. v. Lang and McPherson (1911) 161 Cal. 672, 120 Pac. 421; Nevada School Dist. v. Shoecraft. supra, n. 25; Ex parte Burke, supra, n. 2.

27 (1924) 194 Cal. 93, 100, 227 Pac. 762. 
some distinction, natural, intrinsic or constitutional, which suggests a reason for and justifies the particular legislation. That is to say, not only must the class itself be germane to the purpose of the law, but the individual components of the class must be characterized by some substantial qualifications or attributes which suggest the need for and the propriety of the legislation. Subject to these limitations a law is general despite the fact that it operates only upon a class of individuals or things, if it applies equally to all persons or things within the class to which it is addressed. (Pasadena v. Stimson, 91 Cal. 238; McDonald v. Conniff, 99 Cal. 386; Darcy v. Mayor etc. of San Jose, supra; People v. Central Pacific R. R. Co. 105 Cal. 576; Deyoe v. Superior Court, 140 Cal. 476; Ruperich v. Baehr, 142 Cal. 190; Title etc. Restoration Co. v. Kerrigan, 150 Cal. 389; Ex parte King, 157 Cal. 161 ; Matter of Application of Martin, 157 Cal. 51; Matter of Application of Miller, 162 Cal. 287; In re Sumida, supra; In re Morganstern, 40 Cal. App. Dec. 893.)"

And when proper ground for classification exists, the classification is not void because it does not embrace within it every classification which might be included. ${ }^{28}$

\section{Limitations on Purposes of Legist.ation}

There are other provisions limiting the field of legislation, all of which are found in Article IV of the constitution: Section 22 prohibits the appropriation of money for the benefit of any institution not under the exclusive management of the State, except institutions conducted for the support and maintenance of asylums for orphans, half-orphans, abandoned children or children of a father who is incapacitated for gainful work by permanent physical disability, or who is suffering from tuberculosis in such a stage that he cannot pursue a gainful occupation, or aged persons in indigent circumstances. Section 30 provides that the legislature shall never make an appropriation or grant anything in aid of any religious sect, church, creed or sectarian purpose, or help to support or sustain any school, college, university, hospital or other institution controlled by any religious creed, church or sectarian denomination. Section 31 prohibits the lending of public credit or the making of a gift of any public money or thing of value, except as follows: to institutions under the exclusive control of the state, as provided in section 22; to irrigation districts, for the purpose of

28 Sacramento, etc. Drainage Dist. v. Rector (1916) 172 Cal. 385, 156 Pac. 506. 
acquiring an international water system, and for the purpose of aiding veterans who have served the United States in time of war. Section 32 also provides that the legislature shall have no power to grant any extra compensation or allowance to any public officer, after service has been rendered or a contract has been entered into.

\section{ForM OF BILLS}

There are also certain provisions in the constitution regulating the form of bills. The principal provisions are found in Article IV, section 24 of the constitution, which is, in part, as follows:

"Every act shall embrace but one subject, which subject shall be expressed in its title. But if any subject shall be embraced in an act which shall not be expressed in its title, such act shall be void only as to so much thereof as shall not be expressed in its title. No law shall be revised or amended by reference to its title; but in such case the act revised or section amended shall be re-enacted and published at length as revised or amended".

There are three distinct provisions in this section: first, that every act shall have but one subject; second, that the subject shall be expressed in the title; and third, that the act or section to be revised or amended must be re-enacted and published at length.

\section{Each Act Shald Embrace But One Subject}

The provision requiring that every act shall embrace but one subject has been given a reasonably broad interpretation, and numerous provisions having one general object fairly indicated by the title may be united. ${ }^{29}$

However numerous the provisions of an act may be, if they can be fairly considered as falling within the subject matter of legislation or as proper methods for the attainment of the end sought by the act, there is no conflict with the constitutional provision. ${ }^{30}$

When the general purpose of the act is declared, the details provided for the accomplishment of the purpose will be regarded as necessary incidentals. ${ }^{31}$ But if the act is made of incongruous

29 Ex parte Liddell (1892) 93 Cal. 633. 29 Pac. 251; Ex parte Kohler (1887) 74 Cal. 38, 15 Pac. 36; People v. Parks (1881) 58 Cal. 624; De Witt V. San Francisco (1852) 2 Cal. 289; Murphy v. Bondshu (1905) 2 Cal. App. 249, 83 Pac. 278.

${ }^{30}$ Ex parte Kohler, supra, n. 29.

31 Ex parte Liddell, supra, n. 29. 
parts, or comprehends unconnected or dissimilar subjects to that expressed in the title, it cannot be upheld. ${ }^{32}$

\section{Acts Embracing One Subject}

The following are acts which have been held to embrace but one subject :

"An act entitled 'An act for the better protection of stockholders in corporations formed under the laws of the State of California for the purpose of carrying on and conducting the business of mining,' and providing a penalty for failure to post an itemized account or balance sheet. ${ }^{33}$

"An act entitled 'An act to establish a state reform school for juvenile offenders' and providing for the commitment of juvenile offenders to such school..$^{34}$

"An act entitled 'An act to create the county of Kings, to define the boundaries thereof and to provide for its organization and election of officers and to classify said county, and providing for the collection of taxes levied before the formation of the county. ${ }^{35}$

"An act entitled 'An act to protect and promote the horticultural interests of the state', and declaring certain insect pests public nuisances and making the expense of abating them a lien on the property affected. ${ }^{36}$

"And an act entitled 'An act in relation to foreign corporations', and providing for the designation of agents, service of process and proof of corporate existence." 37

\section{Acts Embracing More Than One Subject}

The following are acts which have been held to embrace more than one subject:

"An act amending the sanitation district act and providing that sanitary boards might determine the qualifications of persons authorized to sell liquor at retail. ${ }^{38}$

"An act entitled 'An act to promote drainage,' and providing for control of debris for mining operations, the improvement of river channels and the erection of embankments to protect lands from inundation. ${ }^{39}$

32 People v. Parks, supra, n. 29.

33 Francais v. Somps (1891) 92 Cal. 503, 28 Pac. 592.

34 Ex parte Liddell, supra, n. 29.

35 Kings Co. v. Johnson (1894) 104 Cal. 198, 37 Pac. 820.

36 Los Angeles County v. Spencer (1899) 126 Cal. 670, 59 Pac. 202, 77 Am. St. Rep. 217.

37 Anglo-Californian Bank v. Field, supra, n. 10.

38 In re Werner (1900) 129 Cal. 567, 62 Pac. 97.

39 People v. Parks, supra, n. 29. 
"An act entitled 'An act to establish fees', and providing for the collection of a tax."

"An act entitled 'An act to establish a uniform system of county and township governments, and providing for salaries for official reporters of the Superior Court, who are state officers." 41

The title of an act may be broader than the provisions of the act itself, and still not render the act unconstitutional under the section. ${ }^{2}$

\section{The Subject Must Be Expressed in tee Title}

The purpose of the provision requiring that the subject of the act should be expressed in the title was to prevent the passage of acts bearing deceitful and misleading titles. ${ }^{43}$

The provision is intended to protect the members of the legislature, as well as the public, against fraud, and to guard against the passage of bills the titles of which give no indication to the members of the legislature or to the people of the substance of the matters contained therein. ${ }^{4 *}$

Where the body of an act embraces provisions which are germane to the general subject stated in its title, the title will be held sufficient to comprehend all of the provisions of the act itself; and when the title suggests the field which the text of the act includes, the title will not be held misleading or insufficient. ${ }^{45}$

Nothing in the constitutional provisions requires that the title shall disclose the purpose and scope of the act. It is enough if it intelligently refers the reader to the subject to which the act applies, or which is affected by it. ${ }^{48}$

So long as the title contains a reasonable intimation of the matters under legislative consideration, the public cannot complain. It has always been the custom to state the subject of a bill in general terms and with the fewest words, and the framers of the constitution doubtless intended the legislature to conform to that custom. ${ }^{47}$

In amending an act passed under the old constitution when full expression of the subject in the title was not mandatory, it is not

40 Fatjo v. Pfister (1897) $117 \mathrm{Cal} .83,48$ Pac. 1012.

41 Pratt v. Browne (1902) 135 Cal. 649, 67 Pac. 1082.

42 Application of Mascolo, supra, n. 23.

43 Ex parte Liddell, supra, n. 29.

44 Matter of Maginnis (1912) 162 Cal. 200, 124 Pac. 827; Matter of Bonds South San Joaquin Irrigation Dist. (1911) 161 Cal. 345, 119 Pac. 198; Abeel y. Clark, supra, n. 8; Park v. Pacific Fire Extinguisher Co. (1918) 37 Cal. App. 112, 173 Pac. 615.

45 People v. Jordan (1916) 172 Cal. 391, 156 Pac. 451.

46 Hellman v. Shoulters (1896) 114 Cal. 136, 44 Pac. 915.

17 Ex parte Liddell, supra, n. 29. 
necessary to state the subject more fully than in the title to the act amended. ${ }^{48}$

Wherever the title of an amending act expresses the subject dealt with, this title is in itself sufficient, independent of the original title."

It has been held that an act entitled "An act to amend section - of the - Code" sufficiently states the subject of the act, ${ }^{50}$ but it is better practice to state in the title of the amendatory act the subject to which the act relates.

\section{Detalls Should Not Be Enumerated in the Titie}

It seems to be well settled that it is not necessary that the title of an act should embrace an abstract or catalogue of its contents. ${ }^{61}$

Mr. Justice Shaw said in Robinson v. Kerrigan, ${ }^{52}$

"If it were necessary to mention every subdivision our statutes would present a somewhat ludicrous appearance. The statement of the subject in the title would generally occupy almost as much space as the act itself."

Titles'which give an abstract of the contents of a bill are frequently found. The following is the title to a bill which amended but one code section. It is an example of the kind of a title to avoid.

"An act to amend section one thousand two hundred and three of the Penal Code, relating to probation of persons arrested for crime, after plea or verdict of guilty and the suspending of the imposition or execution of sentence during the term of probation or the imposition of jail sentence or fine or both or other conditions to fit the crime in connection with probation, and the disposition of such accusation after full compliance with the terms of probation and providing for the creation of offices of adult probation officer, assistant adult probation officer, and deputy adult probation officer in counties, and cities and counties of the first, second, third, fourth, fifth and sixth class, and fixing their compensation and duties and providing for adult probation boards in said counties and cities and counties."

48 People v. Parvin (1888) 74 Cal. 549, 16 Pac. 490.

49 Miller \& Lux v. Sacramento etc. Drainage Dist. (1920) 182 Cal. 252, 187 Fac. 1041.

50 People v. Oates (1904) 142 Cal. 12, 75 Pac. 337.

51 Park v. Pacific Fire Extinguisher Co., supra, n. 44; Ex parte Hallawell (1909) 155 Cal. 112, 99 Pac. 490; People v. Linda Vista Irr. Dist. (1900) 128 Cal. 477, 67 Pac. 86; Hellman v. Shoulters, supra, n. 46; People v. Superior Court (1893) 100 Cal. 105, 34 Pac. 492; Ex parte Liddell, supra, n. 29; Abeel v. Clarke, supra, n. 8.

52 (1907) 151 Cal. 52, 90 Pac. 137. 
A better title would have been:

"An act to amend section one thousand two hundred and three of the Penal Code, relating to adult probation."

It is probable that in the above act with the long title, any detail not mentioned in the enumeration would be held not to be included in the act under the ejusdem generis rule which raises the presumption that when an enumeration is made everything which is not included in the enumeration is intended to be excluded. If the act fixed the salaries of officers in counties of classes other than those enumerated in the title, for example, it is clear that those provisions would be held not to be included in the title.

\section{Amendment by Re-enactment}

There are three possible ways by which an existing statute may be amended. First, the particular words which it is desired to change may be stricken out, and other words may be added or substituted. Second, the section may be re-enacted in the form in which the law is desired to stand, or, third, a new act may be passed, changing the particular provision of the law.

For example, it might be desired to extend the notice required in a particular case from two weeks to four weeks. To amend the act by the first method, the amendatory act might provide that in a certain line of a certain page of the act to be amended the word "two" should be stricken out and the word "four" inserted "in lieu thereof." If the second method were used, the section to be amended would be re-enacted, containing the word "four" instead of the word "two". If the third method were used, a new act would be passed, providing that under the particular conditions a notice of four weeks should be required.

The first method of amending is prohibited in California by the provision of the constitution requiring re-enactment at length.

Of the remaining methods, the second, to re-enact the section in the amended form, is far better than to enact a new law, because it prevents confusion and makes the law less voluminous and easier to find.

It is a sufficient compliance with the provision requiring re-enactment and republication to re-enact the section of the act amended. ${ }^{53}$ But in amending a section, the entire section must be re-enacted. ${ }^{54}$

53 Estate of Campbell (1904) 143 Cal. 623, 77 Pac. 674.

54 City of Los Angeles v. Leland (1909) il Cal. App. 302, 104 Pac. 717. 
With the third form of amendment there is greater danger of changing law which is not intended to be modified. In that case, the original act would be repealed by implication, but would remain on the books.

The constitutional provision requiring reenactment applies only to acts which are in terms revisory or amendatory, and not to an independent act, although such act is inconsistent with some existing statute. $^{\text {ss }}$

Paul Mason

Sacramento, California.

(To be concluded.)

55 Pennie v. Ries (1889) 80 Cal. 266, 22 Pac. 176; Jennings v. Le Roy (1883) 63 Cal. 397. 